\title{
"Institutional adaptation to abrupt changes during and following the financial
}

crisis"

\begin{tabular}{|c|c|}
\hline AUTHORS & $\begin{array}{l}\text { Olena Mykolenko (D https://orcid.org/0000-0002-1988-7401 } \\
\text { Hanna Strokovych (D https://orcid.org/0000-0002-5092-9059 } \\
\text { R http://www.researcherid.com/rid/U-3516-2018 }\end{array}$ \\
\hline ARTICLE INFO & $\begin{array}{l}\text { Olena Mykolenko and Hanna Strokovych (2018). Institutional adaptation to } \\
\text { abrupt changes during and following the financial crisis. Investment Management } \\
\text { and Financial Innovations, 15(1), 154-165. doi:10.21511/imfi.15(1).2018.14 }\end{array}$ \\
\hline DOI & http://dx.doi.org/10.21511/imfi.15(1).2018.14 \\
\hline RELEASED ON & Wednesday, 21 February 2018 \\
\hline RECEIVED ON & Friday, 05 January 2018 \\
\hline ACCEPTED ON & Tuesday, 30 January 2018 \\
\hline LICENSE & $\begin{array}{l}(c) \text { EY } \\
\text { This work is licensed under a Creative Commons Attribution } 4.0 \text { International } \\
\text { License }\end{array}$ \\
\hline JOURNAL & "Investment Management and Financial Innovations" \\
\hline ISSN PRINT & $1810-4967$ \\
\hline ISSN ONLINE & $1812-9358$ \\
\hline PUBLISHER & LLC "Consulting Publishing Company "Business Perspectives" \\
\hline FOUNDER & LLC "Consulting Publishing Company "Business Perspectives" \\
\hline
\end{tabular}

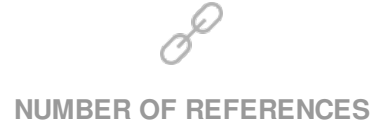

43

\section{NUMBER OF FIGURES}

2
韸

NUMBER OF TABLES

0

(C) The author(s) 2022. This publication is an open access article. 


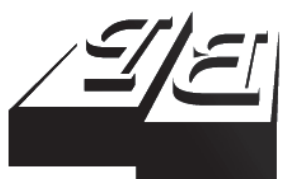

BUSINESS PERSPECTIVES

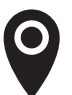

LLC "CPC "Business Perspectives" Hryhorii Skovoroda lane, 10, Sumy, 40022, Ukraine

www.businessperspectives.org

Received on: $5^{\text {th }}$ of January, 2018 Accepted on: $30^{\text {th }}$ of January, 2018

(c) Olena Mykolenko, Hanna Strokovych, 2018

Olena Mykolenko, Ph.D., Associate Professor at the Department of Economics and Law, Kharkiv University of Humanities "People's Ukrainian Academy”, Ukraine.

Hanna Strokovych, Doctor of Science, Associate Professor, Professor at the Department of State Management, Public Administration and Regional Economy, Simon Kuznets Kharkiv National University of Economics, Ukraine.

\section{() (i)}

This is an Open Access article, distributed under the terms of the Creative Commons Attribution 4.0 International license, which permits unrestricted re-use, distribution, and reproduction in any medium, provided the original work is properly cited.

\title{
INSTITUTIONAL ADAPTATION TO ABRUPT CHANGES DURING AND FOLLOWING THE FINANCIAL CRISIS
}

\begin{abstract}
The aim of the study is to investigate substantial bases and mechanisms for institutional changes that facilitate the adjustment of an economic system to abrupt changes. To achieve this objective, comparative analysis is carried out in order to disclose different approaches to crisis management and resolution regimes following the financial imbalances in Denmark, Sweden, and the USA that represent three different models of institutional adaptation. Thus, the paper reflects on the multifaceted phenomenon of institutional change, evaluating the theoretical background, which is further adjusted to the concept of institutional adaptation. In turn, the concept of institutional adaptation is developed from crisis management and post-crisis financial policies' perspective. Built on various resolution procedures, the main mechanisms behind institutional adaptation are highlighted: extension (extended authorities of traditional institutions that have been empowered with additional functions); limited creation (newly-created institutions with restricted opportunity to exercise their discretion); redeployment (utilized and redeployed traditional effective institutions in order to implement new resolution schemes); modified formation (newly-formed institutions that have been modified and adjusted); grafting (grafting the new appropriate elements onto statutory institutional frameworks); transfer (transfer of practices from other domains and markets), and rebuilding (rebuilding functional competences). It is proved that even though policy-makers draw on institutions and logic of actions originally established and developed before the need to respond to new circumstances, they adjust and redesign them to fit and produce a renewed action plan.
\end{abstract}

\section{Keywords}

JEL Classification

\section{INTRODUCTION}

The evolution of economic systems objectively results in a new relationship between endogenous and exogenous factors influencing the economic development through deeper integration and globalization. This requires permanent institutional change to adjust all components and subsystems to a renewable complex environment. Comparative political economists have revolved the discussion about the process of institutional changes, especially those undertaken in response to the opening of markets through deeper integration and globalization (Campbell, 2004; Campbell \& Pedersen, 2007; Crouch, 2005). The authors take up these issues with reference to the most recent financial crisis that has had the impact on leading decision-makers and further financial policies.

The paper doesn't investigate offered explanations and reasons for the financial crisis, but focuses on a series of measures adopted by governments and central banks in response to the looming threat. The paper differentiates a variety of approaches to conceptualizing institu- 
tional adaptation and discusses recent theories based on the various views of institutional change, and theories emphasizing the role of economic agents in these processes. Theoretical explanations for the mechanisms behind institutional adaptation are also considered (Crouch, 2005; Streeck \& Thelen, 2005; Carstensen, 2017). In order to make the theory of institutional change more holistic, complementarity that conveys the stability of some sets of interconnected institutions is considered (Deeg \& Jackson, 2012). Finally, deep theoretical analysis gives the opportunity to develop the concept of institutional adaptation and design its logic through institutional change.

Further, the paper discusses several case studies that describe different measures adopted during and following the financial crisis to resolve ailing financial companies. These cases focus mostly on the relevant reform strategies, including financial policies, macroeconomic policies with regard to the initial institutional conditions. Three countries have been selected, first of all, to explain different approaches to institutional change, and, secondly, to emphasize the importance of adaptations that have been implemented by policy-makers from the onset of the crisis. This paper focuses on application of different institutional mechanisms and makes more detailed comparison of bank crisis management and postcrisis financial policies (Allen \& Moessner, 2010; Andersen et al., 2014; Baily et al., 2017). Thus, the aim of the study is to investigate substantial bases and mechanisms for institutional change that facilitate the adjustment of an economic system to abrupt endogenous and exogenous changes.

The paper proceeds as follows. Section 1 presents the theoretical background on institutional change. Section 2 gives a comparative study - a brief overview of institutional change in Denmark, Sweden, and the USA in the context of crisis management and post-crisis financial regulation. Section 3 discusses the empirical results last section concludes.

\section{THEORETICAL BACKGROUND AND LITERATURE REVIEW}

There are many opinions on the notion of institutional change with respective mechanisms that should be disclosed. This concept is the starting point of the study. Chandler, Williamson and their followers believe that institutional change reflects a functional response to changes in a technical environment within which enterprises run their businesses. Therefore, the more functionally efficient and effective institutions are, the faster they become sustainable and prevailing (Williamson, 1985). Meyer and his colleagues note that it is likely the result of economic actors seeking legitimacy from their peers within a related field; they adhere to principles and practices that are deemed appropriate and legitimate (Meyer et al., 1997). However, this theory is based on the concept that doesn't have thorough theoretical background when it refers to developing countries. The alternative view regards institutional change as driven largely by conflicts and struggles for control and redistribution of valued resources, principal markets and other ways of obtaining economic power (Amable, 2003). In this case, contending interest groups regard the power as an opportunity to change institutions so as to fit their purposes and needs. Thus, the relationship between state and economy is without doubt of significant interest to the study.

Some representatives of institutional theory who support the approach of different varieties of capitalism note that institution establishment may occur through recombination or redistribution of institutional principles and practices in a new and creative way. Or it can be blending of new modified elements into the existing institutional arrangements (Crouch, 2005). These mechanisms can be realized on the basis of residues (crystals) of preceding models, which agents can use to build up a new institutional structure that will serve their interests and needs.

The theory of institutional change is more holistic when it considers complementarity. And this suggests that close relationship between institutions often gives rise to different perspectives. Firstly, economic agents can block institutional change considering indirect influence of new rules on 
their professional occupation and prospects in related fields. And, secondly, it causes consistent change of other institutions since economic agents endeavor to maintain or improve their current positions.

Streeck and Thelen (2005) suggest five mechanisms for institutional change, taking into account the existing gaps between intentions and outcomes of implemented reforms: layering, replacement (displacement), drift, conversion and exhaustion. The first two mechanisms are built on the assessment of alternative strategies in conjunction with the goal settings. Under layering and displacement, economic agents expect that their interests would be better served by new institutional principles and practices. These mechanisms can be implemented when economic agents are active in local politics, and government officials affirm their intention to act. Unlike the preceding mechanisms, drift constitutes gradual changes in a stable environment within which institutions operate. In this case, institutions are adapted to both larger scale and new conditions that extend or alter their functions. Conversion is a process when formal institutions are redirected to new current objectives and functions. Finally, exhaustion means that institutions are no longer able to generate income so as to ensure their existence; or institution functioning is impossible as it accumulates many economic and social problems. Further, Mahoney and Thelen (2010) have made the contribution to the analysis of incremental changes grounded in a power-distributional view of institutions that emphasizes persisted struggle; however, they don't draw much attention to an institutional complementarity. The need to incorporate it into the study has facilitated the development of several perspectives.

Firstly, scientists have drawn the conclusion that the real economy is institutionally complicated and comprised mainly of mixed institutions. Secondly, scholars have unfolded the discussion on complementarity as a mechanism for functioning institutions that compensate for a lack of other institutions. But also it goes to prove its effectiveness when balancing up an opportunistic behavior of economic actors (Crouch, 2005, 2015; Campbell \& Pedersen, 2007).

The literature review proves that evolutionary or gradual changes of institutions have a significant implication for any institutional process. However, this analysis focuses on deliberate institutional reforms that anticipate deep imbalances in a system and make it restored and revamped shortly. In other words, the study focuses on sweeping changes that enable policy-makers to prevent any system from collapse or tremendous disruption. And respective institutional mechanisms considered earlier are very significant for understanding this phenomenon. The author concludes that its implementation features economic agents who have a big amount of influence over a whole institutional process. In the context of institutional theory, Carstensen (2017) suggests the concept of bricolage for understanding how policy-makers create new institutional setup through re-ordering of the existing institutional elements.

Thus, institutional adaptation constitutes the agent-centered institutional change, triggered by coordinated and concerted response (behavior) from economic agents aimed at counteracting the risk of a serious disturbance. And one key issue that has to be considered is the concept of subjectivity of an economic system stemmed from identity, reproduction and realization of economic agents within the entrenched value-oriented institutional frameworks. In other words, institutions facilitate the behavior, which is the result of selfreplication and self-realization of economic agents within the prevailing entrenched values and views. All in all, the logic of institutional adaptation through institutional change can be presented in Figure 1.

The notion encourages us to develop a new insight into the institutional dynamics and investigate how economic systems adapt to abrupt changes. Institutional change undertaken in different countries during and following the financial crisis is the vivid example of how policy-makers, along with other economic agents, have created financial stability; how new laws have been implemented, adjusted, and balanced against economic growth and other crucial factors; how new institutional setup within the existing context has been created through agent-centered institutional change.

The concept of institutional adaptation reveals a prominent role of both state and influential economic agents in these processes. However, built on 


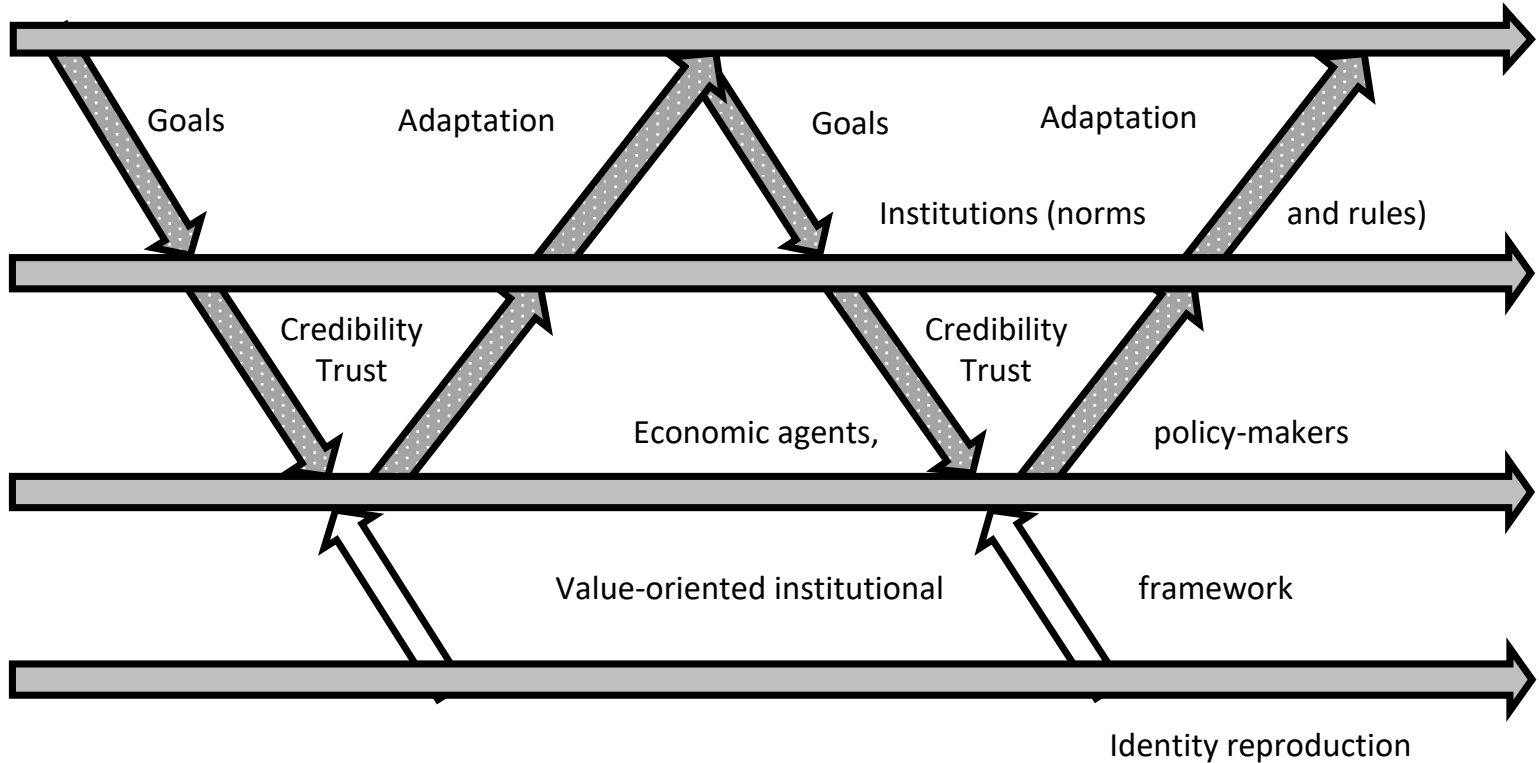

Figure 1. The logic of institutional adaptation through concerted institutional change

the experience of bank crisis management and resolution procedures in Denmark, Sweden, and the United States, the author concludes that all who actively engage in a comprehensive dialogue to solve the current issues are partially constrained in their decisions. The outstanding institutional process is influenced by state interaction with other operating agents with regard to legal interests that they pursue. Interest-based negotiations are increasingly commonplace as a favorable institutional environment could potentially open up new scopes for a number of vested interests (Bell, 2011, p. 898). In addition, more often than not policymaking process involves an activity of policy entrepreneurs who rely on their competences, expertise and invest both time and resources in the knowledge that standards or procedures will become more prudent and appropriate. The contribution of active policy entrepreneurs to a growing consensus around resolution matters is widely recognized in the literature (Mattli \& Woods, 2009).

\section{RESULTS}

The following sections examine different resolution regimes and schemes to illustrate the diversity of mechanisms for institutional changes.

\subsection{Special resolution regimes in Denmark}

Special resolution regimes are invented to avoid traditional corporate approach to bank crisis, namely bankruptcy and bailout of creditors. Regarding a primary objective of corporate bankruptcy, which is to support creditors when a debtor is already insolvent, the new bank resolution policies aim to provide financial stability at the expense of senior creditors, shareholders and, to a certain extent, depositors (Marinc \& Vlahu, 2012).

Policy-makers, drawing on institutions and principles that had been developed before the disruption, came to the conclusion that adaptations were necessary from the onset of the crisis. Respective institutions proved unable to address new circumstances and have been subsequently adjusted. The problems became increasingly apparent with the failure of Roskilde Bank in the summer of 2008 (IMF, 2014). And the first two bank packages were tailored shortly to tackle the urgent financial issues. The initial substantial public intervention in the form of funding guarantees and capital injections following the crisis had the adverse effect on the Danish financial system. Shortly after moving to a new scheme, 
a recapitalization scheme was introduced in order to give the scope for selling bonds to the government. On balance, fifty banks and mortgage lenders applied for capital amounted to EUR 8.2 billion by the closing date. And soon the government drew the conclusion about the crying needs for corrections to moral hazard incentives so as to avoid a drastic economic downturn (Campbell \& Hall, 2014). As a result, several pivotal resolution tools have been designed.

One of the most essential tools in this context is restructuring (recapitalizing) a company through write-down of claims from shareholders or through converting unsecured debts into equity (FSB, 2013). Another crucial resolution tool is a "bridge bank" (subsidiary of the Financial Stability Company) created as a temporary institution to work out an urgent solution. This mechanism suggests that a financial institution which currently doesn't meet solvency requirements takes needed amount of time to find suitable acquirers (with compensation given by the Financial Stability Company). And the other decision is winding up the affected bank with an official transfer of the distressed bank's assets and the part of its liabilities to subsidiaries for new bank establishment (FSB, 2013). One more scheme (Bank Package III) has been constructed to preserve healthy assets of the failing institution. In order for this to work, resolution authorities got the opportunity to split all assets of the distressed bank into two parts so that "sick" assets are placed in a special entity to be liquidated; healthy assets are offered to other banks interested in taking over (Carstensen, 2013). Bank Package III has empowered the authorities to resolve more effectively a number of small and medium-size distressed firms at minimum cost to taxpayers.

Special resolution regime is not just a market-oriented approach, but rather constitutes the institutionalization of a new state role. A certain institutional framework (Bank Package I and Bank Package II) had been already designed before the crisis, but it was not purely implemented. To come up with a serious challenge, the government has created and implemented new mechanisms. A new-found resolution regime allows the authorities to resolve distressed banks in a way that minimizes public sector support by imposing losses on private creditors and owners of financial institu- tions. It aims to ensure the continuity of credit institution's systemically important functions without making use of public funds. According to the logic of new bills, the financial sector, but not the public sector, covers the losses. That influences behavior of all market agents, including financial institutions which have to be more responsible, as well as creditors which have to be more prudent. As a result, all of these institutions have been worked out over four years in five pieces of legislation - "Bank Packages" (Woll, 2014).

A robust institutional framework is of paramount importance to efficient crisis management and bank resolution procedures in Denmark. Firstly, the government involves the relevant organizations (agencies) in allocation of tasks and responsibilities. Secondly, it contributes to establishment of coordination mechanism as an integral part of solving banking crisis that constitutes the institutionalization of traditional cooperation between the banking sector and the state in crisis and postcrisis period (Carstensen, 2013). Thirdly, the experience of Denmark proves an adaptive potential of institutions that might have been developed in one context and reused and redeployed in a very different context. One prominent example is the Guarantee Fund for Depositors that, on the one hand, seeks to promote public confidence to depositors and, on the other hand, takes part in resolution processes due to the current legislation. The latter provides three distinct roles for this agency in resolution matters.

\subsection{Crisis management in Sweden}

Sweden fell into recession in the third quarter of 2008. Drawing on experience and lending practices learned from the early 1990s banking crisis, the Swedish government has actively intervened in the financial system (Jockem, 2010). Initially, the Riksbank (Sweden's central bank) signed a swap agreement with both the US Federal Reserve (FR) and the European Central Bank (ECB) to provide the financial system with the sufficient US dollar liquidity and liquidity in euros to meet the banks' crisis demand for foreign currency liquidity. Before crisis, Swedish financial institutions, especially banking companies, have relied heavily on borrowing and lending across European countries, mostly in US dollars and euros (Bryant et al., 2012). 
Shortly afterwards the government established a credit facility. According to the program, the Riksbank allotted loans amounted to USD 73.3 billion between October 2008 and March 2010 (Hansen et al., 2011). Overall, the bank allotted a total of SEK 958,5 billion in loans with maturities up to 12 months. But, according to the borrowing requirements, only 16 credit institutions were eligible to become monetary counterparties. To fulfill the increased demand for liquidity from other financial institutions, the Riksbank expanded the range of eligible assets in refinancing and payment system, as well as the list of eligible counterparties. Despite the significant capital injections into the industry, the Swedish monetary base increased the least compared to other central banks as a result of actions taken by the Riksbank, which absorbed the surplus liquidity through fine-tuning operations and issuance of debt certificates (Minegishi \& Cournède, 2010).

Sweden adopted a stabilization plan which has been a mix of government expenditure on infrastructure, public employment and a kind of fiscal policies. The country has implemented two stimulus packages in the knowledge of potential risks related to a slump in export demand which the economy had already experienced before 2007. To avoid the perils, the government program covered tax reduction and interest rates cuts due to the existing fiscal space, created in pre-crisis period (Miller et al., 2011). Although the Swedish fiscal institutional frameworks have been widely praised, Boije and Kainelainen (2012) conclude that political commitment and stability inherent in the Sweden economy matter more.

At the beginning of 2009, another package was offered to Swedish banks for recapitalization. It provided for the guarantee in respect of bank debt (Sveriges Riksbank, 2010). In order for this to work, the special Stability Fund was set up as a part of introduced financial program. Financing is supposed to be provided by the financial services industry itself. To this end, the Stability Fund is financed ex ante and all proceeds will cover financing support measures in the future (Schich \& Kim, 2010). If a need exceeds the size of the fund, the National Debt Office will grant the Stability Fund unlimited credit. The Fund in the context of resolution will be used before the deposit insurance fund, and the latter will be applied only in the final stage of procedure.
Overall, the resilience of the financial system has been improved by strengthening the institutional frameworks for regulation and supervision, mainly due to a high responsibility of the government for measures taken, as well as increased cooperation. To ensure close dialogue, the Financial Stability Council comprises representatives from the Ministry of Finance, the Financial Supervisory Authority, the Swedish National Debt Office and the Riksbank (OECD, 2015). This provides the possibilities to make concerted efforts for responding to a looming crisis.

In addition, macroprudential measures have been implemented with regard to the peculiarities of the financial system. Since 2009, the government has adopted more stringent rules to improve the financial system, and the banking system in particular. The Swedish wholesale funding banking sector is still highly concentrated to date with four banks accounting for more than 70 percent of lending market. As a result, systemically important banks are required to hold capital buffer on top of Basel III minimum requirements (OECD, 2017). There are also some additional capital and liquidity requirements for Swedish systemic banks. The latter have been designed especially to counteract household debt accumulation with regard to a surge in both debts and dwelling prices over the past decades (Andersen et al., 2014). The data and statistics illustrate that credit to households has been relatively stable over the last decade with 7-7.5\% y-o-y change in 2016 (OECD, 2017). In general, the financial system survived the crisis quite safely, spurring the economy to faster growth.

\subsection{Special resolution regime in the USA}

Seven years after the financial crisis, the US economy has recovered and surpassed its pre-crisis peak by 10 percent. Economic growth is projected to continue at an annual pace of about 2 percent that is above the level in Denmark and below the level in Sweden (Figure 2).

Housing was without doubt at the heart of the last financial crisis. Its leverage has fallen off since the beginning of the turmoil. Due to loan write-offs and imposed spending limits, household balance 


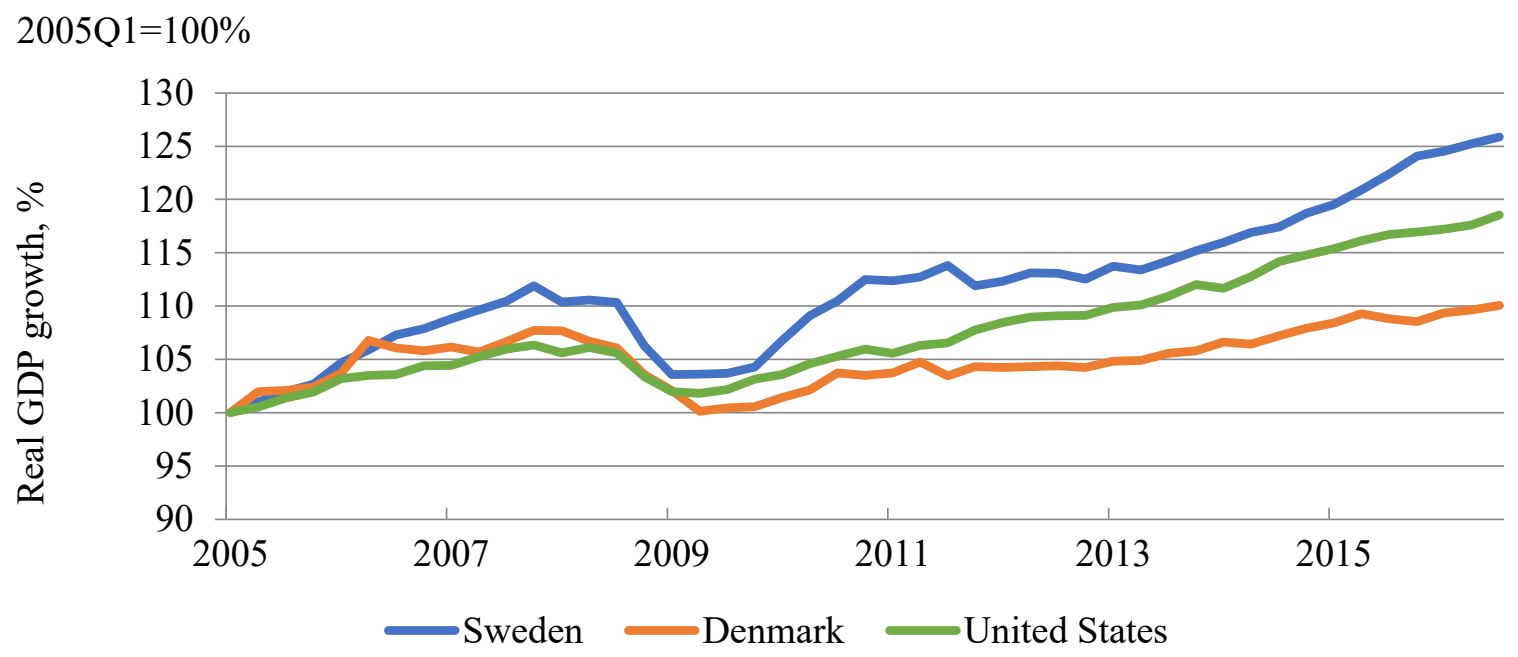

Figure 2. Real GDP in Sweden, Denmark, and the United States

sheets have been put in a more stringent position than prior to the crisis. Spending restraints, by far, impede a successive increase of household debt. As a result, household net worth in USA has risen as a share of disposable income and accounts for about 600 percent of gross disposable income that is above the levels in both Sweden and Denmark (OECD, 2016).

Nevertheless, from the late 2007, the market headed to the recession, and soon afterwards the US Federal Economic Stimulus Act was endorsed. It offered tax rebates to lower- and middle-income Americans, tax cuts to business and increased limits for mortgage purchases (Wanna et al., 2015). But these measures didn't tackle the main financial problems. The bankruptcy of Lehman Brothers in September 2008 triggered legislative initiatives, and Troubled Asset Relief Program (TARP) was introduced. Firstly, it empowered the Treasury to spend up to USD 700 billion to support tainted asset-backed mortgage securities. In particular, Federal National Mortgage Association and Federal Home Mortgage Corporation received USD 126 billion from the government as they guaranteed nearly the half of country's mortgages (Lavelle, 2013).

Another instrument for dealing with ailing financial firms - bailouts with taxpayer funds - was used in the case of American International Group (AIG). A concern for the safety of other system- atically important banks or investment firms and the failure of private crisis management enforced the government to provide a USD 85 billion loan in exchange for a 79.9 percent equity stake in the company. This bailout totally amounted to USD 182 billion by March 2009 (Campbell, 2011).

A third approach to the resolution has been employed in the following cases. Merrill Lynch was sold to the Bank of America, Bear Stearns was merged with JP Morgan Chase, Washington Mutual of Seattle was sold to JP Morgan Chase through the Federal Deposit Insurance Corporation (FDIC) as a receiver. The FDIC, along with the bank's primary regulator, determines when a bank is insolvent and takes it over. The first responsibility of this agency is to protect insured depositors up to USD 250,000. Then it manages the rest of failed bank's assets.

Along with conventional insolvency measures, the crisis compelled both the legislature and the executive to alter traditional approaches. As a result, in June 2009, the Administration issued a White Paper describing measures for regulatory reforms. On July 21, 2010, the President signed a bill that has been implemented in the USA as the DoddFrank Act (DFA). The DFA comprises "resolution procedure" to resolve (dismantle) a big company, including systemically important financial institution (SIFI), if its bankruptcy brings high risks to the system. 
The DFA from the beginning constitutes an important step towards implementation of key attributes of a sound financial system that monitor socalled "systemic risk" (Woolley \& Ziegler, 2011). First of all, the DFA extended the FDIC's authority to resolve ailing firms beyond commercial banks, including entire bank holding companies and all SIFIs. The law also created a new fund to operate these firms - an Orderly Liquidation Authority (OLA) and an Orderly Liquidation Fund (OLF) which is set up by collecting risk-based assessment fees from eligible financial companies (FSB, 2013). According to the strategy, the FDIC will establish a 'bridge' financial company, to which the assets and only some liabilities would be transferred from the old one (Klein, 2017). OLA is considered as one of the most vulnerable portions of the Dodd-Frank Act to date and the bankruptcy code is still the first option for a failing financial firm, leaving OLA as a last resort.

But in some areas, the DFA has made a real progress when created a new Financial Stability Oversight Council (FSOC) to supervise the financial system and ensure enhanced level of regulation for the largest financial institutions. This agency is composed largely of existing regulatory agencies and responsible for macroprudential regulation. FSOC is empowered to subject any non-bank financial institution to a detailed review if the latter could bring disruption to a system. It is difficult to overestimate the role of this agency for financial stability as non-bank financial institutions account for more than 70 percent of the US financial sector assets and more often than not pose a systemic threat. In addition, all financial firms have moved increasingly into multiple parts of modern financial services industry - commercial banking, securities brokerage, investment banking, mortgage lending, and their own proprietary. Despite the fact that FSOC provides regulators with a surveillance mechanism, it still lacks authority to carry out its coordination. It is even not empowered to force regulators to work in conjunction with joint rules when there is a growing need for new institutions (Baily et al., 2017).

A widely approved provision of the DFA concerns the creation of the Consumer Financial Protection Bureau (CFPB) which aims to deal with consumer lending practices and their spillover effects
(Katalina \& Bianco, 2013). Creating a new agency enables regulators to set clear rules and monitor compliance of financial products with standards, whereby removing misleading financial products from the marketplace. The bureau is an institution that had been widely discussed and designed prior to the crisis and then implemented as the legislation progressed (Katalina \& Bianco, 2013). The Bureau has engaged both bank and non-bank lenders, consumers, and policy-makers in tackling a wide range of crucial issues. At the same time, the agency's opportunity to exercise discretion in their decisions is still restricted. In addition, the CFPB goals often ran counter to the objects of some of the most entrenched vested interests in the finance sector, particularly the American Banking Association (Baily et al., 2017).

\section{DISCUSSION}

Since the last financial crisis hit, all countries have embarked on a series of sweeping reforms to respond appropriately to new circumstances. There are some lessons from the implementation of the laws; there are corrections and adjustments aimed at improving the outcomes as well. The empirical evidences prove that institutional adaptation constitutes more than just passing a crucial set of reforms. Preceded events show that even a predictable and preannounced regime for resolving any situation needs prudent new steps toward ending a highly problematic time. Even the best regulatory regime is incapable of preventing all widespread imbalances and crisis. And the latter reveals all weaknesses in the financial system, its regulatory and institutional structure that calls for urgent reforms to enhance and make it resilient, as well as adaptable to the external shocks. When countries confronted with the insolvency of big financial institutions, they employed resolution schemes available at the time and had the option: to bail out failing banks or other companies, thereby using taxpayers' funds, or let ailing institutions fail under conventional bankruptcy legislation resulting in systemic problems and disruptions, or support (finding) another institution to buy a failing firm. After all, the government officials sought to find a third alternative to existing strategies. In the course of the crisis, it became clear that the initial assumptions to a certain extent were incor- 
rect. This enabled policy-makers to embark on a new path of adaptation. Thus, three different models of institutional adaptation that have been designed from crisis management and post-crisis financial policies' perspective are identified.

1. The Dodd-Frank legislation in the USA constitutes a rather ambitious attempt to adapt the existing structure of important financial and regulatory institutions primarily to major shocks. The DFA is an endeavor to institutionalize a new failure resolution regime that seeks to ensure that losses resulting from imprudent decisions of managers will be offset by equity and debt holders of a company. In this sense, the Dodd-Frank legislation is designed to increase financial stability and prevent future devastation from financial stress events. However, the financial regulatory architecture still remains fragmented and not enough rebuilt than it could be, since the periods of "normal' marginal adaptation are interrupted by more infrequent and atypical periods of 'non-linear' policy changes" (Howlett \& Migone, 2011, p. 54). The outstanding political process in the USA has produced the outcome that can be explained by a new form of two-tier politics. Since the officials in their decisions have had to balance grass-roots advocacy organizations with the most powerful interest groups in the country (Woolley \& Ziegler, 2011). For instance, American Bankers Association, along with the US Chamber of Commerce, on the one hand, expressed qualified support and favored macroprudential regulation in the USA. On the other hand, they blocked the proposals of nongovernmental organizations for improvements in regulatory policy.

Nevertheless, the new SPOE approach makes a big difference to the preceding resolution scheme and has more than compensated for a lack of infrastructure for resolving the economic crisis. On the one hand, it ensures that losses will be borne by shareholders and creditors, whereby encouraging market discipline and reducing moral hazard related to government bailouts. On the other hand, the government has expanded the market for institutions in order to build up institutional structure for adapting the system to abrupt changes.

2. The special resolution regimes in Denmark, first of all, provide authorities with a big range of pow- ers to support on a timely basis ailing financial companies. But in practice, more often than not, the authorities have not been very consistent in using their temporary resolution procedures. The Danish experience is rich in plenty of examples how the government had to avoid employing designed scheme under the pressure of international capital markets (for instance, "dowry-scheme") due to a significant openness of the economy and banking system's foreign exposures. Otherwise that could undermine financial stability. Thus, newly-formed institutions under different "Bank Packages" have been continually modified and adjusted in order to apply them efficiently. In the course of resolution procedures, the government also considers binding commitments of the financial system. For instance, the banking sector, which accounts for two-thirds of the financial sector, has the binding ties and agreements with other sectors at regional level (construction and farmers businesses). So any resolution scheme has been addressed with regard to the business interests of related industries.

In contrast to the USA, the Danish government has attached a lot of importance to reorganization and redeployment of existing institutional elements in the context of post-crisis financial regulation. Due to this mechanism, the Danish Guarantee Fund, in line with the Financial Stability Company recreated from a liquidation company, has become the part of the Danish Resolution Scheme and derives resources from ex ante financing (IMF, 2014). However, the primary function of the fund is to cover losses of depositor - up to a certain amount - if a financial institution becomes subject to a winding-up. Thus, the authorities have placed much reliance on the existing institutions to utilize their professional expertise and experience.

The final implementation of a new regulatory policy is seen as laying the basis for the key differentiator between the Danish special resolution regime and the resolution regime in the USA. In the Danish case, it was first tested when Amagerbanken, the fifth largest Denmark's bank, underwent financial problems and was reorganized in February 2011. In addition, that was the first European scheme whereby creditors suffered hair-cuts on their investment (Bloomberg, 2011). This approach contrasts with the one implemented in the USA. The 
government officials will test the new institutional configuration when signs of distress come about in the wake of a new crisis.

3. Sweden took absolutely different course. The government did not just bail out financial companies in the attempt to take over the bad debts. Still other emergency measures were appropriately adopted. Those comprised adaptation of deposit insurance program, extension of collateral arrangements, orderly recapitalization, as well as resolution of financial institutions dealing with possible insolvency (Bryant et al., 2012). And from the onset of the crisis, the Swedish authorities have placed much reliance on the preceding experience and the expertise in post-crisis resolution policy. First of all, built on the key characteristics of the financial system, they identified major risks for the stability at that time. With regard to the benefits and risks, incremental adjustments have been required to influence Sweden's external vulnerability to financial shocks originated abroad of magnitude similar to Denmark's scope. As a result, the crisis response actions included the early arrangements with the US FR and the ECB (Bryant et al., 2012). These crucial arrangements were complemented by the Swedish National Debt Office (SNDO) and its crisis management. Since 2008, the SNDO has been given new powers as a supporting authority under the new law (Government Support to Credit Institutions Act). The most significant part of its package during the crisis was the guarantee program for newly issued debt amounted to 10 percent of GDP at peak times.

But the most important merit of the government officials' work was the catalyzing of cooperative behavior in order to manage urgent financial issues (Allen \& Moessner, 2010). That made it possible to introduce and implement a multitude of reforms. A first set of reforms entailed adjustments fostering the crisis lending programs. A second group of reforms ("crisis management") aimed at adjustments eased regulatory constraints on the accounting practices and behavior of insurance companies (Bryant et al., 2012).

\section{CONCLUSION}

The empirical cases for crisis management and resolution regimes originated in Denmark, Sweden, and the USA prove that institutions do matter. While there is no single solution to the institutional change as such, this article attempts to highlight different mechanisms behind institutional adaptation that have been applied by the government officials to counteract imbalances and disruptions stemmed from the most recent financial crisis.

The empirical lessons hold that institutional adaptation constitutes the agent-centered institutional change, triggered by coordinated and concerted response (behavior) from both governments and economic agents aimed at counteracting the risk of serious imbalances in an economic system. The paper suggests that these changes depend heavily on the existing institutional setup, the presence of institutional complementarities, and the potential for interaction and cooperation between government and contending interest groups. So far the government has played even more active role than other organizations in managing the crisis, considering the scope of its support to large financial firms. The cases with special resolution schemes directed at the financial stability prove that economic systems in the course of institutional adaptation have become quite subjectivized. Precisely because regulatory reforms have been designed and implemented with regard to the impact of a reforming system on the activity of systematically important companies. It is also confirmed that resolution mechanism takes account of inherent characteristics of the financial sector and its exposure to vulnerability of international markets, and of larger firms operating in those markets.

A complete account of actions taken during the crisis to adapt a system would need additional evaluation. The authors cannot feasibly discuss all of them here. Instead, the central ones have been identified to highlight the main mechanisms behind institutional adaptation and show different models through crisis management and post-crisis financial policies' perspective. Institutional adaptation takes different forms. As argued above, the special resolution regimes found in Denmark and the United States haven't entailed fundamental 
changes in the existing institutional setup, but instead have been implemented to develop it while grafting the new elements onto traditional approaches, as well as granting supervisors (agencies) needed authority to deal with a number of ailing financial companies. This is the premise underlying the practice on rebuilding functional competences in some aspect of governmental activity. Transfer of practices from other domains and markets, as well as utilization of existing institutions that proved to be effective in resolving the previous crisis, are the key mechanisms behind institutional adaptation applied by the government in Sweden.

\section{ACKNOWLEDGEMENT}

The authors are grateful for the support provided by Simon Kuznets Kharkiv National University of Economics, project No. 52/2015-2017 "Designing a methodology to investigate socio-economic development of a region on the basis of formation of systemic basis for synthesized capital and information infrastructure".

\section{REFERENCES}

1. Allen, W., Moessner, R. (2010). Central Bank Cooperation and International Liquidity in the Financial Crisis of 2008-9 (BIS Working Papers, No. 310, June). Basel: Bank for International Settlements, Basel. Retrieved from https://www.bis.org/publ/ work310.pdf

2. Amable, B. (2003). The Diversity of Modern Capitalism. New York, NY: Oxford University Press. https://doi. org/10.1093/019926113X.001.0001

3. Andersen, A. L., Duus, C., Jensen, T. L. (2014). Household Debt and Consumption During the Financial Crisis: Evidence from Danish Micro Data (Danmarks Nationalbank Working Papers, No. 201489). Danmarks Nationalbank, Copenhagen. Retrieved from http://www.nationalbanken.dk/da/publikationer/Documents/2014/03/WP_89.pdf

4. Baily, M. N., Klein, A., Schardinc, J. (2017). The Impact of the DoddFrank Act on Financial Stability and Economic Growth. The Russell Sage Foundation Journal of the Social Sciences, 3(1), 20-47. https:// doi.org/10.7758/rsf.2017.3.1.02

5. Bell, S. (2011). Do We Really Need a New 'Constructivist Institutionalism' to Explain Institutional Change? British Journal of Political Science, 41(4), 883-906. https://doi.org/10.1017/ S0007123411000147
6. Bloomberg (2011). Amagerbanken Senior Bondholders to Suffer Losses. Bloomberg, 7 February. Retrieved from http://www.bloomberg (accessed on March 11, 2017).

7. Boije, R., Kainelainen, A. (2012). The Importance of Fiscal Policy Frameworks - Swedish Experience of the Crisis. In Rules and Institutions for Sound Fiscal Policy after the Crisis: Workshops and Conferences (pp. 321-342). Roma: Banca d'Italia.

8. Bryant, R. C., Henderson, D. W., Becker, T. (2012). Maintaining Financial Stability in An Open Economy: Sweden in the Global Crisis and Beyond. Stockholm: SNS Förlag.

9. Campbell, J. L. (2004). Institutional Change and Globalization. Princeton, NJ: Princeton University Press. https://doi.org/10.1017/ S0010417506210363

10. Campbell, J. L. (2011). The US Financial Crisis: Lessons for Theories of Institutional Complementarity. Socio-Economic Review, 9(2), 211-234. https://doi. org/10.1093/ser/mwq034

11. Campbell, J. L., Pedersen, O. K. (2007). The Varieties of Capitalism and Hybrid Success: Denmark in the Global Economy. Comparative Political Studies, 40(3), 307-332. https://doi. org/10.1177/0010414006286542
12. Campbell, J. L., Hall, J. (2014). Small states, Nationalism and Institutional Capacities: The Paradox of the Danish and Irish Responses to the Financial Crisis (Working Paper No. 87). Copenhagen: Copenhagen Business School. Retrieved from Retrieved from http://openarchive. cbs.dk/bitstream/handle/10398/8921/Campbell_2014. pdf? sequence $=3$

13. Carr, E. (2009). A Special Report on the Future of Finance. The Economist, January 25, 1-21.

14. Carstensen, M. B. (2013). Projecting from a Fiction: The Case of Financial Crisis in Denmark. New Political Economy, 18(4), 555-578. https://doi.org/10.1 080/13563467.2013.742881

15. Carstensen, M. B. (2013). The Role of Special Resolution Regimes in Post-Crisis Financial Regulation: Four Danish Lessons. Politik, 16(4), 44-51.

16. Carstensen, M. B. (2017). Institutional Bricolage in Times of Crisis. European Political Science Review, 9(1), 139-160. https://doi. org/10.1017/S1755773915000338

17. Crouch, C. (2005). Capitalist Diversity and Change: Recombinant Governance and Institutional Entrepreneurs. Oxford: Oxford University Press. https://doi.org/0.1093/acprof:o so/9780199286652.001.0001 
18. Crouch, C. (2015). Governing Social Risks in Post-Crisis Europe. Cheltenham: Edward Elgar Publishing Ltd. https://doi. org/10.1177/0950017016682190

19. Deeg, R., Jackson, G. (2012). The Long-Term Trajectories of Institutional Change in European Capitalism. Journal of European Public Policy, 19(8), 1109-1125. https://doi.org/10.1080/13501763.2 012.709001

20. Financial Stability Board (FSB) (2013). Thematic Review on Resolution Regimes: Peer Review Report, April 13. Retrieved from http://www.fsb.org/wp-content/uploads/Second-peer-review-reporton-resolution-regimes.pdf (accessed on July 19, 2017).

21. Hansen, Niels-Jakob H., Welz, P. (2011). Interest Rate Pass-through During the Global Financial Crisis. The Case of Sweden (OECD Economics Department Working Papers No. 855). OECD Publishing, Paris. https://doi. org/10.1787/5kgdx1j025ln-en

22. Howlett, M., Migone, A. (2011). Charles Lindblom is Alive and Well and Living in Punctuated Equilibrium Land. Policy and Society, 30, 53-62. https://doi.org/10.1016/j. polsoc.2010.12.006

23. International Monetary Fund (IMF) (2014). Denmark: Financial Sector Assessment Program: Crisis Management, Bank Resolution, and Financial Sector Safety Nets - Technical Note (IMF Country Report No. 14/351). International Monetary Fund, Washington DC.

24. Jockem, S. (2010). Sweden Country Report. Managing the Crisis: A Comparative Assessment of Economic Governance in 14 Economies. Gutersloh: Bertelsmann Stiftung.

25. Katalina, M., Bianco, J. D. (2013). Consumer Financial Protection Bureau: Evolution of a New Agency with Emerging Regulatory Framework. Wolters Kluwer.

26. Klein, A. (2017). A Primer on Dodd-Frank's Orderly Liquidation Authority. Brookings Papers on Economic Activity, June. Retrieved from https://www.brookings.edu/ blog/up-front/2017/06/05/aprimer-on-dodd-franks-orderly- liquidation-authority/ (accessed on July 9, 2017).

27. Lavelle, K. C. (2013). Money and Banks in the American Political System. New York: Cambridge University Press.

28. Mahoney, J., Thelen, K. (2010). A Theory of Gradual Institutional Change, In J. Mahoney \& $\mathrm{K}$. Thelen (Eds), Explaining Institutional Change: Ambiguity, Agency, and Power. New York: Cambridge University Press. https://doi.org/10.1017/ CBO9780511806414.003

29. Marinc, M., Vlahu, R. (2012). The Economics of Bank Bankruptcy Law. Berlin: Springer-Verlag, Heidelberg. https://doi.org/10.1007/978-3-64221807-1

30. Mattli, W., Woods, N. (2009). The Politics of Global Regulation. Princeton: Princeton University Press.

31. Meyer, J. W., Frank, D. J., Hironaka, A., Schofer, E., Tuma, N. B. (1997). The Structuring of a World Environmental Regime, 18701990. International Organization, 51(4), 623-651. https://doi. org/10.1162/002081897550474

32. Miller, A. T., Holmes, K. R., Kim, A. B., Riley, B., Roberts, J. M., Walsh, K. (2011). 2011 Index of Economic Freedom. The Heritage Foundation. The Wall Street Journal. Retrieved from https://www.heritage.org/ index/pdf/2011/index2011_highlights.pdf

33. Minegishi, M., Cournède, B. (2010). Monetary Policy Responses to the Crisis and Exit Strategies (OECD Economics Department Working Papers No. 753). Paris: OECD Publishing. https://doi. org/10.1787/5kml6xm7qgs6-en

34. Organization for Economic Cooperation and Development (OECD) (2015). OECD Economic Surveys: Sweden 2015. OECD Publishing. Retrieved from http:// www.oecd.org/eco/surveys/Sweden2015-overview.pdf (accessed on March 25, 2017).

35. Organization for Economic Cooperation and Development (OECD) (2016). OECD Economic Surveys: Denmark 2016. OECD Publishing. Retrieved from http:// www.oecd.org/eco/surveys/ Denmark-2016-OECD-economicsurvey-overview.pdf (accessed on March 30, 2017).

36. Organization for Economic Cooperation and Development (OECD) (2016). OECD Economic Surveys: USA 2016. OECD Publishing. Retrieved from https:// www.oecd.org/eco/surveys/UnitedStates-2016-overview.pdf (accessed on March 30, 2017).

37. Organization for Economic Cooperation and Development (OECD) (2017). OECD Economic Surveys: Sweden 2017. OECD Publishing. Retrieved from http:// www.oecd.org/eco/surveys/Sweden2015-overview.pdf (accessed on March, 25, 2017).

38. Schich, S., Kim, Byoung-Hwan (2010). Systemic Financial Crisis: How to Fund Resolution. OECD Journal: Financial Market Trends. Retrieved from http://www. oecd.org/finance/financial-markets/46681329.pdf (accessed on May 1, 2017).

39. Streeck, W., Thelen, K. (Eds). (2005). Introduction: Institutional Change in Advanced Political Economies, In Beyond Continuity: Institutional Change in Advanced Political Economies (pp. 1-39). NY: Oxford University Press. httpx://doi.org/10. 1111/j.1467-8543.2009.00746

40. Wanna, J., Lindquist, E. A., de Vries J. (2015). The Global Financial Crisis and its Budget Impacts in OECD Nations: Fiscal Responses and Future Challenges. Cheltenham: UK Edward Elgar Publishing.

41. Williamson, O. (1985). The Economic Institutions of Capitalism. New York: Free Press.

42. Woll, C. (2014). The Power of Collective Inaction. Ithaca: Cornell University Press.

43. Woolley, J. T., Ziegler, J. N. (2012). The Two-tiered Politics of Financial Reform in the United States. In R. Mayntz (Ed.), Institutional Change in the Regulation of Financial Markets (pp. 27-63). Cologne: Max Planck Institute for the Study of Societies. Retrieved from http:// irle.berkeley.edu/files/2011/TheTwo-Tiered-Politics-of-FinancialReform-in-the-United-States.pdf 